\title{
13C NMR analysis reveals a link between L-glutamine metabolism, D-glucose metabolism and $\gamma$-glutamyl cycle activity in a clonal pancreatic beta-cell line
}

\author{
L. Brennan ${ }^{1}$, M. Corless ${ }^{1}$, C. Hewage ${ }^{1}$, J. P. G. Malthouse ${ }^{1}$, N. H. McClenaghan ${ }^{2}$, P. R. Flatt ${ }^{2}$, P. Newsholme ${ }^{1}$ \\ ${ }^{1}$ Department of Biochemistry, Conway Institute of Biomolecular and Biomedical Research, University College Dublin, Belfield, \\ Dublin, Ireland \\ ${ }^{2}$ School of Biomedical Sciences, University of Ulster, Coleraine, N. Ireland
}

\begin{abstract}
Aims/hypothesis. Pancreatic islet cells and clonal betacell lines can metabolise L-glutamine at high rates. The pathway of L-glutamine metabolism has traditionally been described as L-glutamine $\rightarrow$ L-glutamate $\rightarrow 2$-oxoglutarate $\rightarrow$ oxidation in TCA cycle following conversion to pyruvate. Controversially, the metabolism of D-glucose to L-glutamate in beta cells is not widely accepted. However, L-glutamate has been proposed to be a stimulation-secretion coupling factor in glucose-induced insulin secretion. We aimed to investigate the metabolism of glutamine and glucose by using ${ }^{13} \mathrm{C}$ NMR analysis.

Methods. BRIN-BD11 cells were incubated in the presence of $16.7 \mathrm{mmol} / 1\left[1-{ }^{13} \mathrm{C}\right]$ glucose, $2 \mathrm{mmol} / \mathrm{l}[2-$ $\left.{ }^{13} \mathrm{C}\right] \mathrm{L}$-glycine or $2 \mathrm{mmol} / 1\left[1,2-{ }^{13} \mathrm{C}\right]$ glutamine in the presence or absence of other amino acids or inhibitors. After an incubation period the cellular metabolites were extracted using a PCA extract procedure. After neutralisation, the extracts were prepared for analysis using ${ }^{13} \mathrm{C}$-NMR spectroscopy.
\end{abstract}

Results. Using ${ }^{13} \mathrm{C}$ NMR analysis we have shown that L-glutamine could be metabolised in BRIN-BD11 cells via reactions constituting part of the $\gamma$-glutamyl cycle producing glutathione. Moderate or high activities of the enzymes required for these pathways of metabolism including glutaminase, $\gamma$-glutamyltransferase and $\gamma$-glutamylcysteine synthetase were observed. We additionally report significant D-glucose metabolism to L-glutamate. Addition of the aminotransferase inhibitor, aminooxyacetate, attenuated Lglutamate production from D-glucose.

Conclusion/interpretation. We propose that L-glutamine metabolism is important in the beta cell for generation of stimulus-secretion coupling factors, precursors of glutathione synthesis and for supplying carbon for oxidation in the TCA cycle. D-glucose, under appropriate conditions, can be converted to L-glutamate via an aminotransferase catalysed step. [Diabetologia (2003) 46:1512-1521]

Keywords Pancreatic beta cells, NMR, $\gamma$-glutamyl cycle, L-glutamine, L-glutamate, glutathione.

\section{Introduction}

L-glutamine circulates at the highest concentration of any amino acid (approximately $0.7 \mathrm{mmol} / \mathrm{l}$ ) and its

Received: 5 March 2003 / Revised: 26 May 2003

Published online: 4 September 2003

C) Springer-Verlag 2003

Corresponding author: P. Newsholme, Department of Biochemistry, Conway Institute of Biomolecular and Biomedical Research, University College Dublin, Belfield, Dublin 4, Ireland

E-mail: philip.newsholme@ucd.ie

Abbreviations: NMR, Nuclear Magnetic Resonance. metabolism is essential to the function of a large number of cells and tissues (reviewed in [1]). In the pancreatic beta cell, involvement of L-glutamine metabolism in cellular function and the regulation of insulin secretion is controversial. L-glutamine is readily metabolised in islets and beta-cell lines such as BRINBD11 [2, 3]. Additionally L-glutamate which is derived intracellularly from L-glutamine has been suggested to be a key messenger in the $\mathrm{K}^{+}{ }_{\text {ATP }}$ independent (amplifying) pathway of glucose-induced insulin release $[4,5]$. These and other aspects of beta-cell Lglutamine and L-glutamate metabolism are represented schematically (Fig. 1). However, L-glutamine alone only weakly stimulates insulin secretion $(0.7$ 


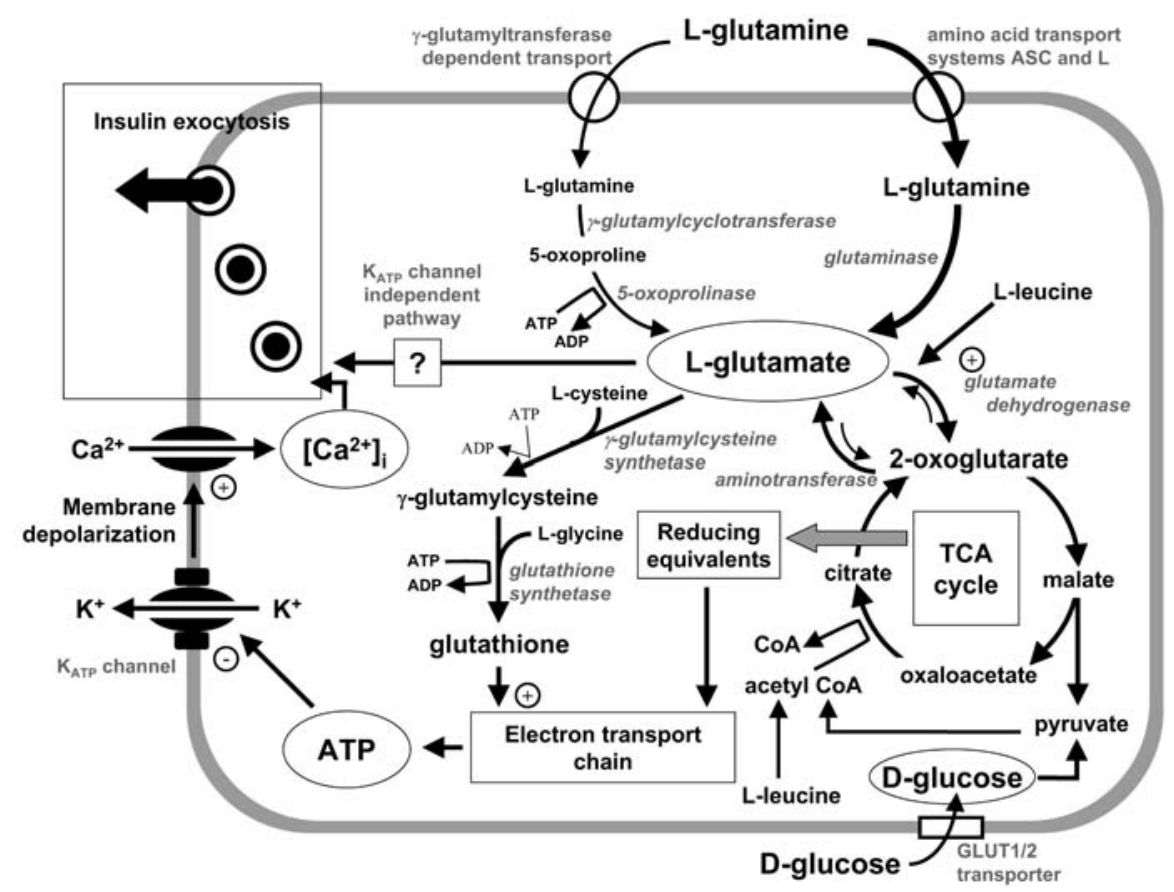

Fig. 1. A schematic representation of L-glutamine and L-glutamate metabolism in the beta cell. L-glutamine is transported into the beta cell by the ASC and L amino acid transporters and subsequently converted to L-glutamate by glutaminase. It is also possible that L-glutamine enters the cell via $\gamma$-glutamyltransferase-dependent transport and subsequently be converted to L-glutamate. L-glutamate could directly affect insulin secretion. L-glutamate is converted to 2-oxoglutarate via glutamate dehydrogenase and thus could enter reactions of the TCA cycle culminating in ATP production. For L-glutamine-derived carbon to be fully oxidised, the carbon must leave the cycle as malate and be converted to pyruvate and then acetyl-CoA via the enzymes $\mathrm{NADP}^{+}$-dependent malate dehydrogenase and pyruvate dehydrogenase respectively. However, L-glutamate can be converted to glutathione by reactions involving L-cysteine and L-glycine which form part of the $\gamma$-glutamyl cycle, e.g. $\gamma$ glutamylcysteine synthase and glutathione synthetase. Glutathione can enhance mitochondrial function and thus promote insulin secretion under appropriate conditions

compared to approximately $1.0 \mathrm{ng} / 10^{6}$ cells per 20 min in BRIN-BD11 cells when glutamine was increased from 0 to $10 \mathrm{mmol} / \mathrm{l}$ glutamine in the presence of $1.1 \mathrm{mmol} / \mathrm{l}$ glucose [6]) and several recent papers question the proposed link between L-glutamate production and enhanced rates of exocytosis $[7,8]$. The question therefore arises as to the functional significance of L-glutamine metabolism in the beta cell.

A key enzyme in the metabolism of L-glutamine, mitochondrial glutamate dehydrogenase $(\mathrm{GDH}$; EC 1.4.1.3) catalyses reversible oxidative deamination of L-glutamate to 2-oxoglutarate. GDH activity, as measured in vitro, is high in pancreatic beta cells [9] and in cell lines such as BRIN-BD11 [10]. However the activity of the enzyme is tightly regulated in vivo by negative and positive effectors such as GTP, ADP and leucine. L-glutamine alone, which can be transported into the cell by a number of potential transport mechanisms [11] is rapidly converted into L-glutamate and other metabolic intermediates intracellularly, but either has little effect or only weakly stimulates insulin secretion $[6,8]$. However, in the presence of leucine or its non-metabolizable analogue, $\mathrm{BCH}$, L-glutamine potently enhances insulin secretion $[12,13]$. Leucineactivated GDH is considered to enhance L-glutamate oxidation and increase ATP production by providing the TCA cycle with substrate (2-oxoglutarate), which by further metabolism and entry into the TCA cycle via acetyl-CoA, will close plasma membrane $\mathrm{K}^{+}{ }_{\text {ATP }}$ channels and stimulate insulin secretion (Fig. 1). In support of this hypothesis it is known that patients with rare mutations in the inhibitory GTP-binding allosteric site on GDH show increased rates of insulin secretion, resulting in hypoglycaemia $[14,15,16]$.

A recent study has shown that unregulated overexpression of GDH in MIN6 cells enabled glutamine alone to stimulate insulin secretion [17]. This was interpreted by the authors to indicate that activation of GDH enhances oxidation of L-glutamate which stimulates insulin secretion [17]. In contrast to this mechanism, glucose has been shown to inhibit the pathway of glutaminolysis (partial L-glutamine metabolism and oxidation involving conversion to glutamate, 2oxoglutarate and related TCA cycle derived products [12]). However, while islet L-glutamate concentration was not altered in the presence of L-glutamine plus glucose compared to glutamine alone, the L-glutamate concentration was reduced when islets were incubated in the presence of glucose and $\mathrm{BCH}$ (2-amino-2-norbornane-carboxylic acid), a condition which enhanced insulin secretion [7]. Thus the proposed role of L-glutamate as an important metabolic coupling factor, required for the amplifying pathway of glucose-stimu- 
lated insulin secretion $[5,18]$ is difficult to reconcile with the available experimental evidence.

Amino acids can enter the beta cell via specific transport proteins $[10,19]$. L-glutamine was reported to enter the cell primarily by the transport systems ASC and L [10]. It is then converted to L-glutamate by the action of glutaminase (Fig. 1). Glutaminase from pancreatic islets was unaffected by ammonia but inhibited by L-glutamate [20]. It has been suggested that in the presence of leucine both a high glutaminase activity and a high flux through GDH are necessary for enhanced insulin secretion. However, L-glutamine could be transported into the cell via $\gamma$-glutamyltransferase [21, 22] (Fig. 1). Despite an early report of beta-cell $\gamma$-glutamyl cycle activity [23] this route of glutamine metabolism has largely been ignored.

We have investigated the metabolism of L-[1,2$\left.{ }^{13} \mathrm{C}\right]$ glutamine, L- $\left[2-{ }^{13} \mathrm{C}\right]$ glycine and $\mathrm{D}-\left[1-{ }^{13} \mathrm{C}\right]$ glucose in the presence of glutamine in the insulin secreting cell line BRIN-BD11. Our ${ }^{13} \mathrm{C}$ NMR data provides new evidence for substantial metabolism of L-glutamine resulting in formation of L-glutamate, L-aspartate and glutathione. The hypothesis that D-glucose is converted into L-glutamate in the beta cell is controversial. However, we have shown previoustly, using ${ }^{13} \mathrm{C}$ NMR, that glucose is converted to L-glutamate in the beta cell [24]. This is difficult to reconcile with the common perception that GDH is operating in the direction of L-glutamate $\rightarrow 2$-oxoglutarate in physiological conditions in the beta cell. Using ${ }^{13} \mathrm{C}$ NMR analysis we report that an aminotransferase is responsible for the 2-oxoglutarate $\rightarrow$ L-glutamate flux in the betacell. We propose that L-glutamate production is important to the beta cell, not because of a direct effect of the amino acid, but as a component of the $\gamma$-glutamyl cycle thus maintaining cellular glutathione concentration. Glutathione concentration has previously been positively correlated with insulin secretion [25].

\section{Materials and methods}

Reagents. D-[1-13C]glucose was obtained from Goss Scientific (Great Baddow, Essex, UK), [1,2-13C]glutamine was obtained from Cambridge Isotope Laboratories (Mass., USA) and [2$\left.{ }^{13} \mathrm{C}\right]$ glycine was supplied by Aldrich (Milwaukee, USA). All other chemicals were obtained from Sigma-Aldrich Chemical (Poole, Dorset UK). Culture media and fetal bovine serum were obtained from Gibco (Glasgow, UK).

Culture and cellular extraction of BRIN-BD11 cells. Clonal insulin-secreting BRIN-BD11 cells were maintained in RPMI1640 tissue culture medium with $10 \%$ (v/v) fetal bovine serum, $0.1 \%$ antibiotics $(100 \mathrm{U} / \mathrm{ml}$ penicillin and $0.1 \mathrm{mg} / \mathrm{ml}$ streptomycin) and $11.1 \mathrm{mmol} / \mathrm{l} \mathrm{D}$-glucose, $\mathrm{pH}$ 7.4. The origin and characteristics of BRIN-BD11 cells are described in detail elsewhere $[26,27,28,29,30]$. The cells were maintained at $37^{\circ} \mathrm{C}$ in a humidified atmosphere of $5 \% \mathrm{CO}_{2}$ and $95 \%$ air using a Forma Scientific incubator. Cells were washed with phosphate-buffered saline and preincubated at $37^{\circ} \mathrm{C}$ for $20 \mathrm{~min}$ in Krebs Ringer bicarbonate buffer with $1.1 \mathrm{mmol} / \mathrm{l}$
D-glucose $\left(10 \mathrm{ml}\right.$ per $\mathrm{T} 182 \mathrm{~cm}^{2}$ flask, $115 \mathrm{mmol} / \mathrm{l} \mathrm{NaCl}$, $4.7 \mathrm{mmol} / \mathrm{l} \mathrm{KCl}, 1.28 \mathrm{mmol} / 1 \mathrm{CaCl}_{2}, 1.2 \mathrm{mmol} / \mathrm{l} \mathrm{KH}_{2} \mathrm{PO}_{4}$, $1.2 \mathrm{mmol} / 1 \mathrm{MgSO}_{4} \cdot 7 \mathrm{H}_{2} \mathrm{O}, 10 \mathrm{mmol} / \mathrm{l} \mathrm{NaHCO}_{3}, 5 \mathrm{~g} / \mathrm{l}$ bovine serum albumin, $\mathrm{pH}$ 7.4) in a humidified atmosphere of $5 \%$ $\mathrm{CO}_{2}$ and $95 \%$ air using a Forma Scientific incubator. This was followed by an incubation period of $1 \mathrm{~h}$ in Krebs Ringer bicarbonate buffer as described above but supplemented with: $2 \mathrm{mmol} / \mathrm{l}\left[1,2-{ }^{13} \mathrm{C}\right] \mathrm{L}$-glutamine, $1 \mathrm{mmol} / \mathrm{l}\left[2-{ }^{13} \mathrm{C}\right] \mathrm{L}$-glycine, or $16.7 \mathrm{mmol} / \mathrm{l}\left[1-{ }^{13} \mathrm{C}\right] \mathrm{D}$-glucose plus different combinations of amino acids. For the aminotransferase inhibition experiment the cells were exposed to the aminotransferase inhibitor aminooxyacetate $(5 \mathrm{mmol} / \mathrm{l})$ in the presence of $16.7 \mathrm{mmol} / \mathrm{l}$ [1$\left.{ }^{13} \mathrm{C}\right] \mathrm{D}$-glucose. After incubation, the medium was removed and stored at $-20^{\circ} \mathrm{C}$ and the cells were washed with phosphate-buffered saline. Perchloric acid $(6 \%)$ was added and the cells were scraped off the culture flasks. The extracts of six culture flasks (approximately $10^{8}$ cells in total) were pooled and centrifuged at $1500 \mathrm{rpm}$. The resulting supernatant was neutralised with $\mathrm{KOH}(5 \mathrm{~mol} / 1$ and $0.1 \mathrm{~mol} / \mathrm{l}$ solutions $)$ and the pellets were soaked overnight in $0.1 \mathrm{~mol} / 1 \mathrm{NaOH}$. The protein concentration was determined using the Lowry method [31]. The neutralised supernatant was centrifuged $(1500 \mathrm{rpm})$ and the supernatant was treated with Chelex-100 resin and then lyophilised. Each experiment was carried out on at least two independent cultures of the BRIN-BD11 cells.

NMR spectroscopy. The lyophilised cell extracts were dissolved in $3 \mathrm{ml}$ potassium phosphate buffer $(100 \mathrm{mmol} / \mathrm{l}$, $\mathrm{pH}$ 7.0) and then centrifuged. The supernatant was carefully removed and $10 \% \mathrm{D}_{2} \mathrm{O}$ was added and the $\mathrm{pH}$ checked and adjusted when necessary with $0.1 \mathrm{~mol} / 1 \mathrm{NaOH}$ and $0.1 \mathrm{~mol} / 1$ $\mathrm{HCl}$. An insert containing $5 \% \mathrm{v} / \mathrm{v}$ dioxane in water was used as an external signal intensity reference for quantification of the NMR spectra. A solution of L-alanine, L-glutamate, lactate and D-glucose, each at a concentration of $100 \mathrm{mmol} / \mathrm{l}$, was prepared and used to quantitate concentrations of metabolites in the ${ }^{13} \mathrm{C}$ spectra. Proton decoupled ${ }^{13} \mathrm{C}$ spectra were acquired on a Bruker DRX 500 spectrometer using a $10 \mathrm{~mm}$ broadband probe. Typically spectra were acquired with $32 \mathrm{~K}$ data points using $9.4 \mu \mathrm{s}$ pulses (90 ${ }^{\circ}$ pulse angle), $260 \mathrm{ppm}$ spectral width, 2 s relaxation delay and 12000 scans. Spectra were recorded at $25^{\circ} \mathrm{C}$. Chemical shifts in aqueous media were referenced to tetramethylsilane at $0 \mathrm{ppm}$ as described previously [32]. Data were processed with no zero filling using Bruker WINNMR software and exponential multiplications with $2 \mathrm{~Hz}$ line broadening were carried out. The assignments of the intermediate metabolites were made by comparison with chemical shift tables in the literature [33] or by addition of $100 \mathrm{mmol} / \mathrm{l}$ of unlabelled amino acid. The amount of ${ }^{13} \mathrm{C}$ in each resonance was evaluated by integration of the extract peaks and the corresponding peaks in the standard sample relative to the dioxane signal. In the case of $\left[1,2-{ }^{13} \mathrm{C}\right]$-proline the amount of ${ }^{13} \mathrm{C}$ was estimated by using peak heights and a known concentration of dioxane, assuming both have similar line widths. Corrections for the natural abundance signal were made. The absolute enrichments of the L-glutamate were related to the glutamate concentration in the extracts, determined by enzymatic methods, to give the specific enrichments [34].

Measurement of glutamine consumption. For the measurement of glutamine consumption, cells were grown in T182 $\mathrm{cm}^{2}$ flasks. When confluent the cells were washed with phosphatebuffered saline and incubated at $37^{\circ} \mathrm{C}$ for $2 \mathrm{~h}$ in Krebs Ringer bicarbonate buffer with $1.1 \mathrm{mmol} / \mathrm{l} \mathrm{D}$-glucose and $2 \mathrm{mmol} / \mathrm{l}$ glutamine or $16.7 \mathrm{mmol} / \mathrm{l} \mathrm{D}$-glucose and $2 \mathrm{mmol} / \mathrm{l}$ glutamine. At $0 \mathrm{~h}$ and $2 \mathrm{~h}$ media $(500 \mu \mathrm{l})$ was removed and centrifuged at 
$900 \mathrm{rpm}$ for $5 \mathrm{~min}$. The amount of glutamine in each sample was determined as described below.

Enzymatic determinations of metabolites. Lactate concentrations were measured using a lactate oxidase based assay kit supplied by Sigma. Cellular L-glutamate concentration was quantified using a glutamate dehydrogenase based assay (Roche Diagnostics, Darmstadt, Germany). Total glutathione concentrations were determined using an assay kit supplied by Dojindo (Kumamato, Japan). The assay is based on the reaction of glutathione with DTNB [5,5'-Dithiobis (2-nitrobenzioc acid)] to form 2-nitro-5-thiobenzoic acid which has an absorption maximum at $412 \mathrm{~nm}$. Oxidised glutathione is also formed which is recycled to glutathione. Glutamine was measured using a protocol previously described [35].

Measurement of glutaminase activity. Glutaminase activity was measured as the amount of L-glutamate formed from glutamine. Cells were washed with phosphate-buffered saline and an extraction buffer consisting of $100 \mathrm{mmol} / \mathrm{l}$ phosphate buffer, $1 \mathrm{mmol} / \mathrm{l}$ EDTA, $50 \mathrm{mmol} / \mathrm{l}$ Tris- $\mathrm{HCl}$ at $\mathrm{pH} 8.6$ was added. The cells were scraped off and sonicated. The experiment was carried out in a final volume of $1 \mathrm{ml}$ and the assay buffer consisted of $50 \mathrm{mmol} / \mathrm{l}$ phosphate buffer, $0.2 \mathrm{mmol} / \mathrm{l}$ EDTA, $50 \mathrm{mmol} / \mathrm{l}$ Tris- $\mathrm{HCl}$ and $0.05 \%(\mathrm{v} / \mathrm{v})$ triton-X-100 at $\mathrm{pH} 8.6$. Cell homogenate and glutamine $(20 \mathrm{mmol} / \mathrm{l})$ were added and incubated for $20 \mathrm{~min}$ at $37^{\circ} \mathrm{C}$. The reaction was stopped by adding $200 \mu \mathrm{l}$ ice cold $\mathrm{HClO}_{4}(25 \%)$. The solution was neutralised with $\mathrm{KOH}$ and centrifuged (1500 rpm). L-glutamate was then measured in the supernatant. Blanks were incubated in the absence of cell homogenate. The protein concentration was measured using the Lowry method. The final results are averages of five determinations $\pm \mathrm{SD}$.

Measurement of $\gamma$-glutamyltransferase activity. BRIN-BD11 cells were scraped off the culture dish in Tris-HCl $(100 \mathrm{mmol} / \mathrm{l}$, $\mathrm{pH}$ 9.0) and sonicated. The $\gamma$-glutamyltransferase activity was measured using an assay kit supplied by Sigma (Poole, Dorset UK) based on the transfer of the glutamyl group from L-glutamyl-p-nitroanilide to glycylglycine over a 20-min incubation period. The p-nitroaniline formed was diazotized and the absorbance was measured at $540 \mathrm{~nm}$. This absorbance is proportional to the $\gamma$-glutamyltransferase activity. The assay was done on six independent cell cultures.

Measurement of $\gamma$-glutamylcysteine synthetase. Cells were washed with phosphate-buffered saline and an extraction buff- er consisting of $50 \mathrm{mmol} / \mathrm{l}$ Tris- $\mathrm{HCl}$ and $1 \mathrm{mmol} / \mathrm{l}$ EDTA at $\mathrm{pH} 8.6$ was added. The cells were scraped off and sonicated. The activity was determined using a method described previously [36] with $2 \mathrm{mmol} / \mathrm{l} \mathrm{L}$-glutamate and $10 \mathrm{mmol} / \mathrm{l} \alpha$-aminobutyrate as substrates in the presence of $\mathrm{MgCl}_{2}(20 \mathrm{mmol} / \mathrm{l})$ and ATP $(5 \mathrm{mmol} / \mathrm{l})$. After incubation for $1 \mathrm{~h}$ the reaction was terminated by adding $10 \%$ trichloroacetic acid. The inorganic phosphate released was determined. The enzyme inhibitor, Lmethione-S-sulphoximine, was used to determine the non-specific inorganic phosphate formation. These values were subtracted from the total value to give the activity of $\gamma$-glutamylcysteine synthetase. The protein concentration was measured using the Lowry method.

Statistical analysis. The results are presented as mean \pm SD. Groups of data were compared using a Student's unpaired $t$ test. Differences were considered significant at a $p$ value of less than 0.05 .

\section{Results}

Metabolism of [1,2-13C]glutamine. When BRINBD11 cells were incubated for $1 \mathrm{~h}$ in $\left[1,2-{ }^{13} \mathrm{C}\right]$ glutamine, the observed end products of metabolism were $\left[1,2-{ }^{13} \mathrm{C}\right]$ glutamate, $\left[1-{ }^{13} \mathrm{C}\right]$ aspartate, $\left[4-{ }^{13} \mathrm{C}\right]$ aspartate, $\left[1,2-{ }^{13} \mathrm{C}\right] 5$-oxoproline and $\left[1-{ }^{13} \mathrm{C}\right]$ glutamate (Fig. 2). It is clear from these results that L-glutamine is rapidly converted in BRIN-BD11 cells to L-glutamate and then to measurable end-products of metabolism e.g aspartate (via oxidation in the TCA cycle). Unexpectedly a proportion of L-glutamine was converted to 5-oxoproline, which is an intermediate of the $\gamma$-glutamyl cycle. This could occur by L-glutamine conversion to 5-oxoproline via $\gamma$-glutamyltranspeptidase and $\gamma$-glutamylcyclotransferase. Glutamate could be formed subsequently by the action of 5-oxoprolinase. However, it is also possible that some of the intracellular 5-oxoproline was formed from spontaneous decomposition of L-glutamine. The absence of enhanced insulin secretion from BRIN-BD11 cells reported when $10 \mathrm{mmol} / \mathrm{l} \mathrm{L}$-glutamine was added to a $16.7 \mathrm{mmol} / \mathrm{l} \mathrm{D}$-glucose stimulus [6] might have been

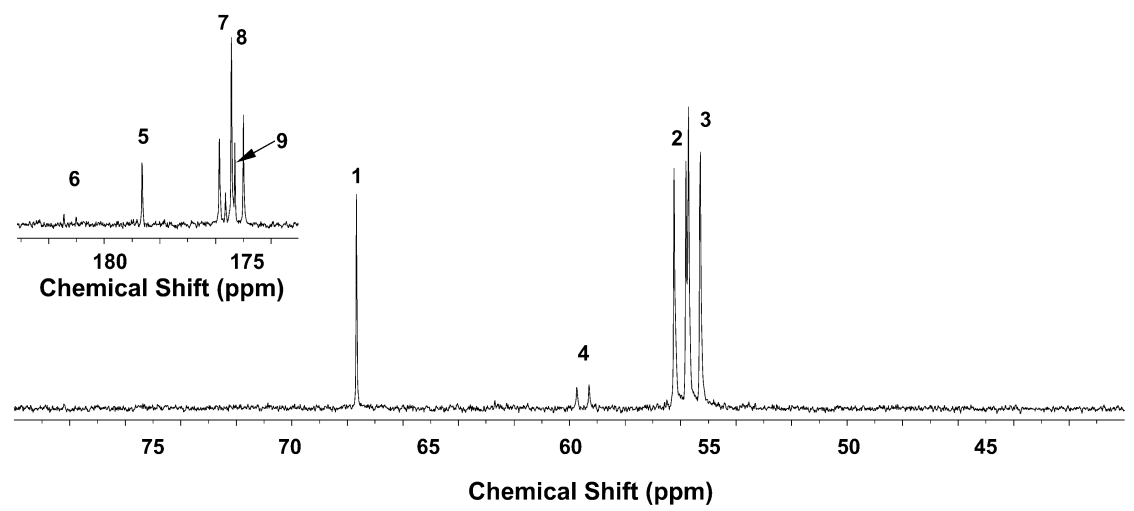

Fig. 2. Sections of a typical $\left[{ }^{1} \mathrm{H}\right.$-decoupled $]{ }^{13} \mathrm{C}-\mathrm{NMR}$ spectrum of an extract from BRIN-BD11 cells after $1 \mathrm{~h}$ of incubation in the presence of $2 \mathrm{mmol} / 1\left[1,2-{ }^{13} \mathrm{C}\right]$ glutamine. Carbon signals appear as doublets for doubly labelled compounds due to carbon-carbon one bond coupling. Annotations: 1, dioxane; 2, glutamate $\mathrm{C} 2 ; 3$, glutamine $\mathrm{C} 2 ; 4$, 5-oxoproline $\mathrm{C} 2$; 5, aspartate $\mathrm{C} 4 ; 6$, 5-oxoproline $\mathrm{C} 1 ; 7$, glutamate $\mathrm{C} 1$; 8 , glutamine $\mathrm{C} 1 ; 9$, aspartate $\mathrm{C} 1$ 


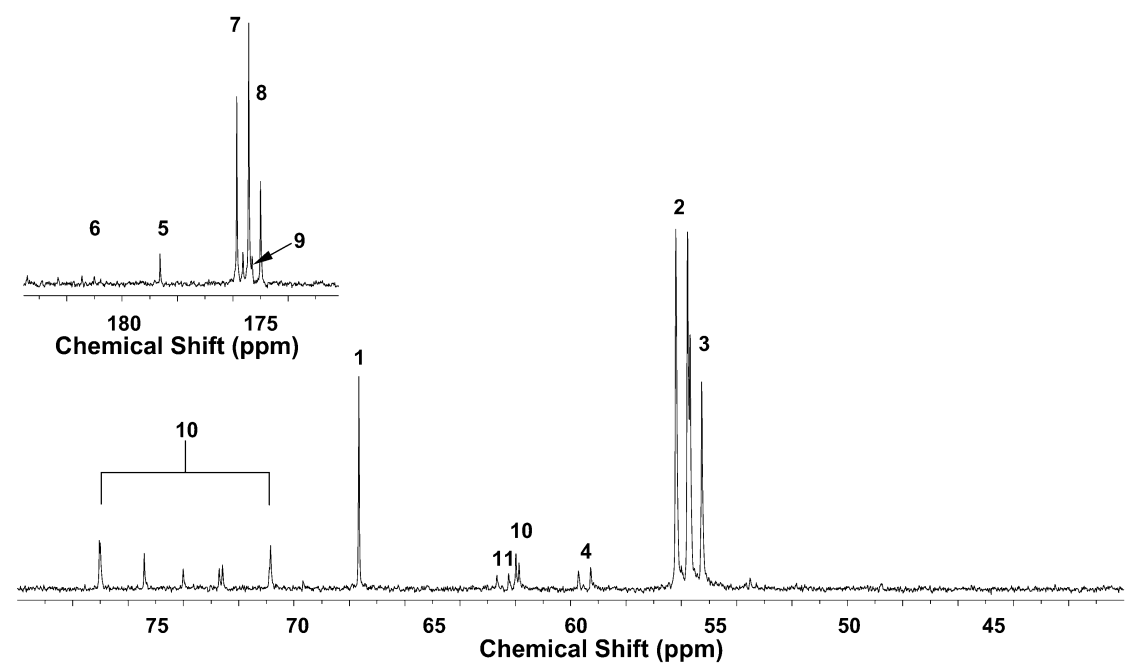

Fig. 3. Sections of a typical $\left[{ }^{1} \mathrm{H}\right.$-decoupled $]{ }^{13} \mathrm{C}-\mathrm{NMR}$ spectrum of an extract from BRIN-BD11 cells after $1 \mathrm{~h}$ of incubation in the presence of $2 \mathrm{mmol} / \mathrm{l}\left[1,2-{ }^{13} \mathrm{C}\right]$ glutamine and $16.7 \mathrm{mmol} / \mathrm{l}$ glucose. Carbon signals appear as doublets for doubly labelled compounds due to carbon-carbon one bond coupling. Annotations: 1, dioxane; 2, glutamate C2; 3 glutamine $\mathrm{C} 2$; 4, 5-oxoproline $\mathrm{C} 2 ; 5$, aspartate $\mathrm{C} 4 ; 6$, 5-oxoproline $\mathrm{C} 1 ; 7$, glutamate $\mathrm{C} 1 ; 8$, glutamine $\mathrm{C} 1 ; 9$, aspartate $\mathrm{C} 1$; 10 , natural abundance glucose; 11 , proline $\mathrm{C} 2$

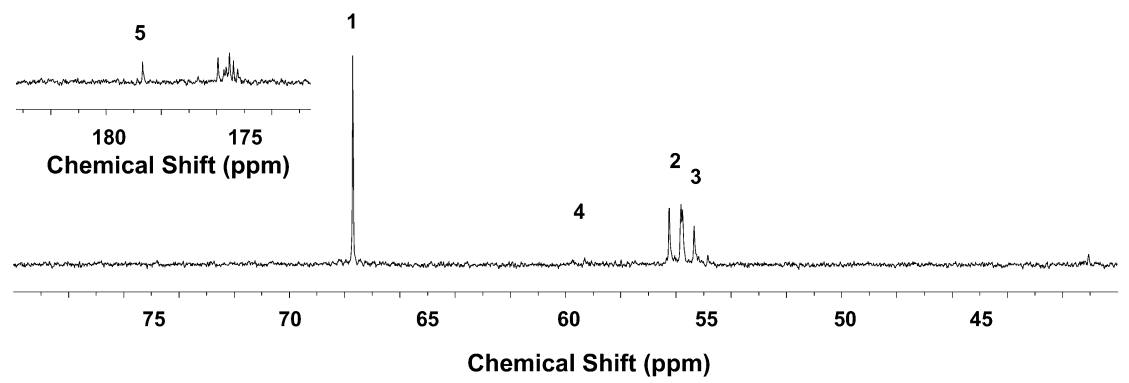

Fig. 4. Sections of a typical $\left[{ }^{1} \mathrm{H}\right.$-decoupled $]{ }^{13} \mathrm{C}-\mathrm{NMR}$ spectrum of an extract from BRIN-BD11 cells after $1 \mathrm{~h}$ of incubation in the presence of $2 \mathrm{mmol} / \mathrm{l}\left[1,2-{ }^{13} \mathrm{C}\right]$ glutamine and $10 \mathrm{mmol} / \mathrm{l}$ leucine. Carbon signals appear as doublets for dou-

Table 1. Rates of L-glutamine consumption in the presence of $1.1 \mathrm{mmol} / \mathrm{l}$ or $16.7 \mathrm{mmol} / \mathrm{l} \mathrm{D}$-glucose

\begin{tabular}{ll}
\hline Incubation condition & $\begin{array}{l}\text { Rate of } \\
\text { L-glutamine } \\
\text { consumption }\end{array}$ \\
\hline $2 \mathrm{mmol} / \mathrm{l} \mathrm{L}$-glutamine $+1.1 \mathrm{mmol} / \mathrm{l}$ glucose & $0.41 \pm 0.08$ \\
$2 \mathrm{mmol} / \mathrm{l} \mathrm{L}$-glutamine $+16.7 \mathrm{mmol} / \mathrm{l}$ glucose & $0.39 \pm 0.04$ \\
\hline
\end{tabular}

Values are $\mu \mathrm{mol}$ L-glutamine consumed/mg protein/2 $\mathrm{h} \pm \mathrm{SD}$ $(n=6)$

due to glucose inhibiting the rate of metabolism of Lglutamine. To test this hypothesis, the consumption of glutamine was measured in the presence and absence of glucose. Glutamine consumption was not significantly changed when $16.7 \mathrm{mmol} / \mathrm{l}$ glucose was added to the incubation medium (Table 1). BRIN-BD11 cells were additionally incubated for $60 \mathrm{~min}$ with $\left[1,2-{ }^{13} \mathrm{C}\right]$ glutamine in the absence (Fig. 2 ) or presence (Fig. 3) of glucose. When $16.7 \mathrm{mmol} / \mathrm{l}$ of glucose was bly labelled compounds due to carbon-carbon one bond coupling. Annotations: 1, dioxane; 2, glutamate C2; 3, glutamine C2; 4, 5-oxoproline C2; 5, aspartate C4

added there was a reduction in the peaks due to [4$\left.{ }^{13} \mathrm{C}\right]$ aspartate and $\left[1-{ }^{13} \mathrm{C}\right]$ aspartate (data for $\mathrm{C} 4$ shown in Table 2). The peaks due to glutamate also increased. Since the consumption of glutamine did not change we can assume that the same amount of glutamine entered the cell. Hence the increase in glutamate peaks was a result of decreased entry of glutamate into the TCA cycle. The observation of aspartate labelled at position $\mathrm{C} 1$ and $\mathrm{C} 4$ in the presence of unlabelled glucose, showed that glutamine can act as an energy substrate in the TCA cycle even in the presence of glucose. The ${ }^{13} \mathrm{C}$ enrichment of aspartate at positions $\mathrm{C} 1$ and $\mathrm{C} 4$ are very similar (Table 2) indicating that there is no preferential enrichment of these carbon atoms and thus no evidence for enzyme-to-enzyme channelling of Krebs cycle intermediates. Also a peak due to $\left[1,2-{ }^{13} \mathrm{C}\right]$ proline was observed (Fig. 3, signal 11 , estimated as $15.4 \pm 2.5 \mathrm{nmol} / \mathrm{mg}$ protein).

In the presence of $10 \mathrm{mmol} / \mathrm{l} \mathrm{L}$-leucine there was a decrease in the intensities of glutamine, glutamate and aspartate peaks (Fig. 4). These reductions are possibly 


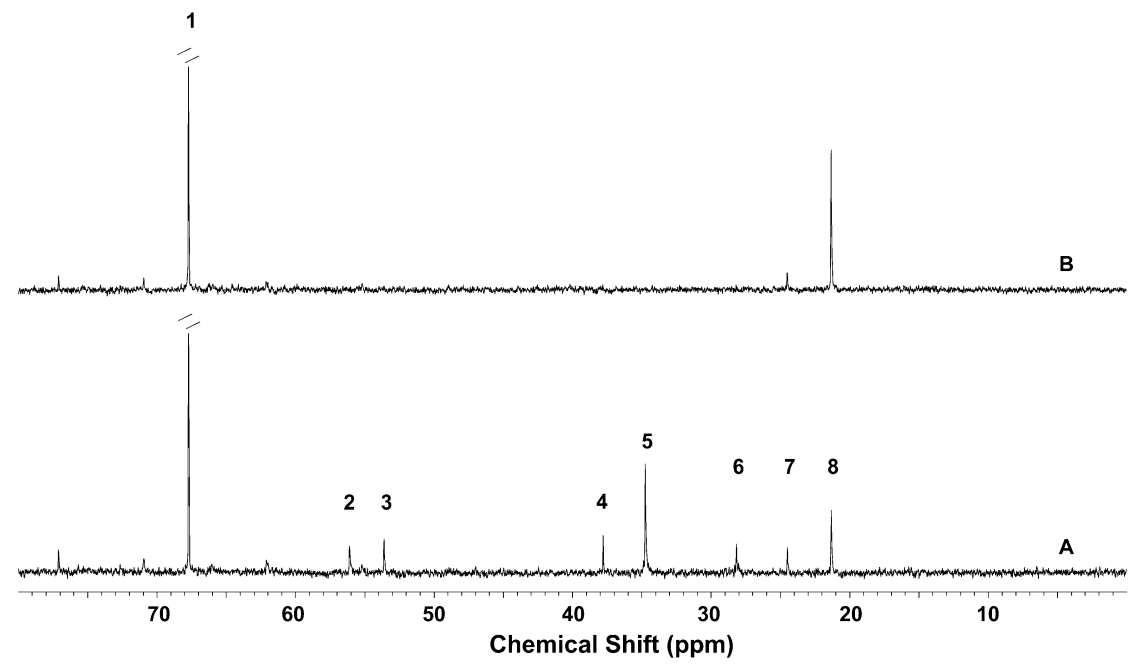

Fig. 5. Sections of typical $\left[{ }^{1} \mathrm{H}\right.$-decoupled ${ }^{13} \mathrm{C}-\mathrm{NMR}$ spectra of extracts from BRIN-BD11 cells after $1 \mathrm{~h}$ of incubation in the presence of (A) $16.7 \mathrm{mmol} / \mathrm{l} \quad\left[1-{ }^{13} \mathrm{C}\right] \quad$ D-glucose (B) $16.7 \mathrm{mmol} / \mathrm{l}\left[1-{ }^{13} \mathrm{C}\right]$ D-glucose plus $5 \mathrm{mmol} / \mathrm{l}$ of the amino-

transferase inhibitor aminooxyacetate. Annotations: 1, dioxane; 2, glutamate $\mathrm{C} 2 ; 3$, aspartate $\mathrm{C} 2 ; 4$, aspartate $\mathrm{C} 3 ; 5$, glutamate $\mathrm{C} 4 ; 6$, glutamate $\mathrm{C} 3 ; 7$, acetate; 8 , lactate $\mathrm{C} 3$

Table 2. Concentrations of labelled intracellular glutamate and aspartate derived from metabolism of D-[1-13C]glucose or L-[1,2$\left.{ }^{13} \mathrm{C}\right]$ glutamine respectively

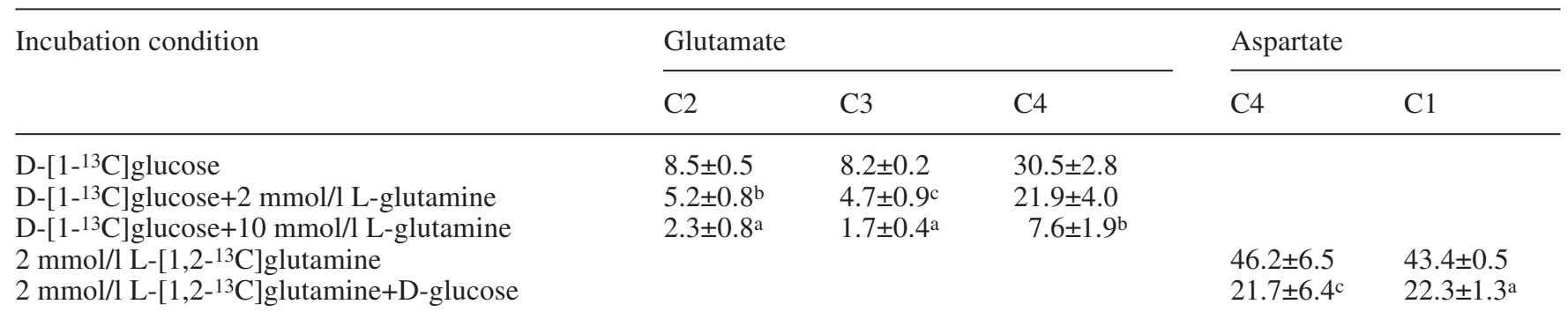

Concentrations are given as $\mathrm{nmol} / \mathrm{mg}$ protein \pm SD. $n=2-3$. ${ }^{\mathrm{a}} p<0.005,{ }^{\mathrm{b}} p<0.01,{ }^{\mathrm{c}} p<0.05$ when compared to control values (16.7 mmol/1 D-[1-13C]glucose or $2 \mathrm{mmol} / 1 \mathrm{~L}-\left[1,2-{ }^{13} \mathrm{C}\right]$ glutamine)

due to a decrease in the transport of labelled L-glutamine into the cell as L-leucine is competing for transport [11] or alternatively due to metabolism of L-leucine which would result in competition with L-glutamine for oxidation. When the lower concentration of $2 \mathrm{mmol} / \mathrm{l} \mathrm{L}$-leucine was added to the BRIN-BD11 incubation medium the peak intensities of ${ }^{13} \mathrm{C}$-labelled glutamate and glutamine both increased with respect to those obtained in the presence of $10 \mathrm{mmol} / \mathrm{l} \mathrm{L-leu}$ cine, thus suggesting that more L-glutamine is entering the cell when a lower L-leucine concentration was used.

Effect of the aminotransferase inhibitor aminooxyacetate on metabolism. When the cells were incubated in the presence of aminooxyacetate there was no observable production of L-glutamate from $16.7 \mathrm{mmol} / \mathrm{l}$ [1${ }^{13}$ C]glucose (Fig. 5). Lactate was observed in the NMR spectrum indicating functional beta-cell glycolytic activity under these conditions (Fig. 5).
D-glucose when present was added at a concentration of $16.7 \mathrm{mmol} / \mathrm{l}$

When the cells were incubated in the presence of aminooxyacetate and L-glutamine there was no inhibition of the production of L-glutamate from L-glutamine.

Effect of L-glutamine on D-glucose metabolism. To investigate the effect of L-glutamine on the metabolism of $\left[1-{ }^{13} \mathrm{C}\right]$ glucose, BRIN-BD11 cells were incubated in $16.7 \mathrm{mmol} / 1 \mathrm{D}-\left[1{ }^{-13} \mathrm{C}\right]$ glucose plus L-glutamine $(2 \mathrm{mmol} / \mathrm{l}$ and $10 \mathrm{mmol} / \mathrm{l})$. In the presence of L-glutamine, the amount of label incorporated from $\left[1-{ }^{13} \mathrm{C}\right] \mathrm{glu}-$ cose into glutamate $\mathrm{C} 2, \mathrm{C} 3$ and $\mathrm{C} 4$ decreased significantly (Table 2). This suggests that the conversion of labelled 2-oxoglutarate to labelled glutamate was reduced in the presence of L-glutamine. The total amount of glutamate increased whereas the specific enrichment decreased indicating that a larger percentage of glutamate is unenriched in the presence of L-glutamine (Table 3). There were no statistically significant changes in the amount of labelled lactate and alanine. 


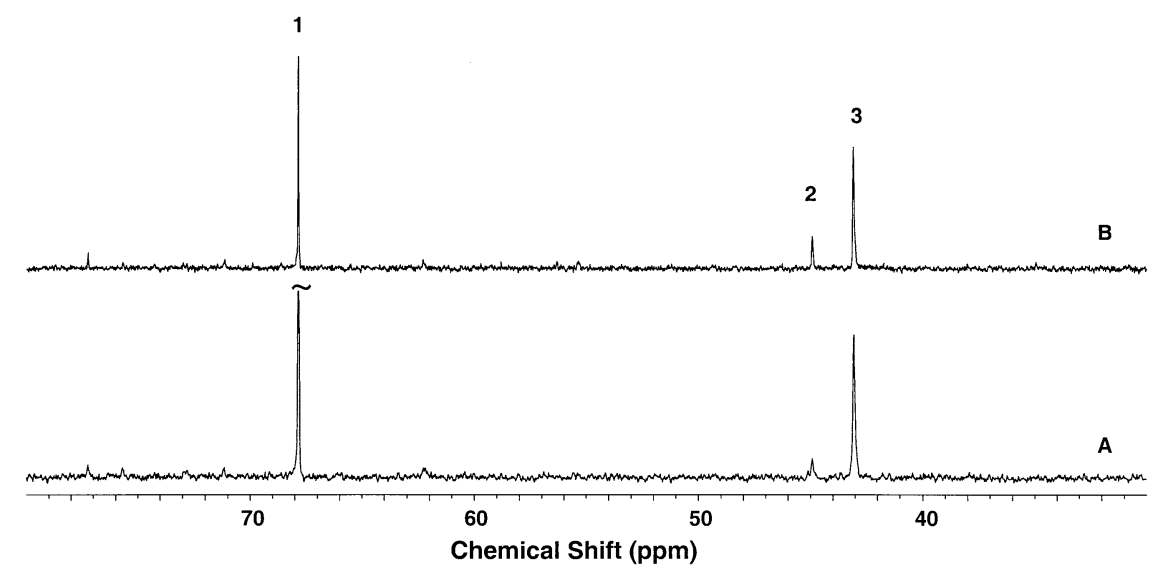

Fig. 6A, B. Sections of typical $\left[{ }^{1} \mathrm{H}\right.$-decoupled] ${ }^{13} \mathrm{C}-\mathrm{NMR}$ spectra of extracts from BRIN-BD11 cells after $1 \mathrm{~h}$ of incubation in the presence of $(\mathbf{A}) 1 \mathrm{mmol} / 1$ [2-13 C]glycine plus $1 \mathrm{mmol} / \mathrm{l}$ cysteine and $16.7 \mathrm{mmol} / \mathrm{l}$ glucose $(\mathbf{B}) 1 \mathrm{mmol} / \mathrm{l}\left[2-{ }^{13} \mathrm{C}\right]$ glycine plus $1 \mathrm{mmol} / \mathrm{l}$ cysteine, $16.7 \mathrm{mmol} / \mathrm{l}$ glucose and $2 \mathrm{mmol} / \mathrm{l} \mathrm{glu}-$ tamine. Annotations: 1, dioxane; 2, glutathione; 3, glycine C2

Table 3. Percent ${ }^{13} \mathrm{C}$ enrichments of the carbon positions of glutamate after incubation with $[1-13 \mathrm{C}]$ glucose or $\left[1-{ }^{13} \mathrm{C}\right] \mathrm{glu}-$ cose plus L-glutamine

\begin{tabular}{|c|c|c|c|}
\hline \multirow[t]{2}{*}{ Incubation condition } & \multicolumn{3}{|l|}{ Glutamate } \\
\hline & $\mathrm{C} 2$ & $\mathrm{C} 3$ & $\mathrm{C} 4$ \\
\hline D-[1-13C]glucose & $10.50 \pm 0.01$ & $9.0 \pm 0.9$ & $30.4 \pm 1.6$ \\
\hline $\begin{array}{l}\mathrm{D}-\left[1-{ }^{13} \mathrm{C}\right] \text { glucose } \\
\quad+2 \mathrm{mmol} / \mathrm{l} \mathrm{L} \text {-glutamine }\end{array}$ & $3.9 \pm 0.9^{\mathrm{a}}$ & $3.8 \pm 0.8^{\mathrm{a}}$ & $18.3 \pm 1.7^{\mathrm{a}}$ \\
\hline
\end{tabular}

All glucose concentrations are $16.7 \mathrm{mmol} / \mathrm{l}$. Values are percent ${ }^{13} \mathrm{C}$ enrichments $\pm \mathrm{SD}, n=2-3$

${ }^{a} p<0.05$ when compared to control values (D-[1-13C]glucose)

Table 4. Total cell glutathione determined in the presence of glucose, L-glutamine or both

\begin{tabular}{lc}
\hline Experiment & $\begin{array}{c}\text { Glutathione } \\
\text { concentration }\end{array}$ \\
\hline $1.1 \mathrm{mmol} / \mathrm{l}$ glucose & $8.9 \pm 1.1$ \\
$16.7 \mathrm{mmol} / \mathrm{l}$ glucose & $17.0 \pm 1.4^{\mathrm{b}}$ \\
$16.7 \mathrm{mmol} / \mathrm{l}$ glucose $+2 \mathrm{mmol} / \mathrm{l} \mathrm{L-glutamine}$ & $22.5 \pm 1.2^{\mathrm{c}}$ \\
$1.1 \mathrm{mmol} / 1$ glucose $+2 \mathrm{mmol} / \mathrm{l} \mathrm{L-glutamine}$ & $21.5 \pm 1.1^{\mathrm{a} \mathrm{d}}$
\end{tabular}

Glutathione concentrations are given in $\mathrm{nmol} / \mathrm{mg}$ protein $\pm \mathrm{SD}$ $(\mathrm{n}=3)$. ${ }^{\mathrm{a}} \mathrm{p}<0.0001,{ }^{\mathrm{b}} \mathrm{p}<0.005$ compared to $1.1 \mathrm{mmol} / \mathrm{l}$ glucose and ${ }^{\mathrm{c}} \mathrm{p}<0.01,{ }^{\mathrm{d}} \mathrm{p}<0.05$ compared to $16.7 \mathrm{mmol} / \mathrm{l}$ glucose

Effect of L-glutamine on cellular glutathione concentration. Total glutathione concentrations were measured in the cellular extracts after incubation in $1.1 \mathrm{mmol} / \mathrm{l}$ glucose, $16.7 \mathrm{mmol} / \mathrm{l}$ glucose, $1.1 \mathrm{mmol} / \mathrm{l}$ glucose plus $2 \mathrm{mmol} / \mathrm{l}$ glutamine or $16.7 \mathrm{mmol} / \mathrm{l} \mathrm{glu}-$ cose plus $2 \mathrm{mmol} / \mathrm{l}$ glutamine (Table 4). On increasing extracellular glucose concentration to $16.7 \mathrm{mmol} / \mathrm{l}$ or addition of $2 \mathrm{mmol} / \mathrm{l}$ glutamine to $1.1 \mathrm{mmol} / \mathrm{l}$ or
$16.7 \mathrm{mmol} / \mathrm{l}$ glucose there were increases in the amount of total glutathione present. When the BRINBD11 cells were incubated with $1 \mathrm{mmol} / 1$ [2-13 C]glycine (a precursor of glutathione synthesis) in the presence of $1 \mathrm{mmol} / \mathrm{l} \mathrm{L}$-cysteine and $16.7 \mathrm{mmol} / \mathrm{l}$ glucose glutathione appeared in the NMR spectrum labelled at the glycine position (Fig. 6A). On addition of $2 \mathrm{mmol} / \mathrm{l}$ glutamine the intensity of the glutathione peak increased (Fig. 6B, signal 2).

Activities of glutaminase, $\gamma$-glutamyltransferase and $\gamma$ glutamylcysteine synthetase. The glutaminase activity measured in optimal conditions $(50 \mathrm{mmol} / \mathrm{l}$ phosphate) in BRIN-BD11 cells $(69.9 \pm 7.3 \mathrm{nmol} / \mathrm{mg}$ protein $/ \mathrm{min})$ was similar to that reported previously [20]. The activity was found to be phosphate dependent, decreasing to $47.4 \pm 3.2 \mathrm{nmol} / \mathrm{mg}$ protein $/ \mathrm{min}$ in the presence of $10 \mathrm{mmol} / \mathrm{l}$ phosphate in agreement with an earlier report of beta-cell phosphate-dependent glutaminase activity [20]. The activity of $\gamma$-glutamyltransferase in BRIN-BD11 cells, measured under optimal conditions, was $66 \pm 12 \mathrm{nmol} / \mathrm{mg}$ protein $/ 60 \mathrm{~min}$, considerably lower than the value of $0.80 \pm 0.12 \mathrm{nmol} / \mu \mathrm{g}$ protein $/ 60 \mathrm{~min}$ reported for islets [23]. The presence of $\gamma$-glutamyltransferase activity in BRIN-BD11 cells could be important for cellular function. The activity of $\gamma$-glutamylcysteine synthetase, the rate limiting enzyme for glutathione production, was found to be $110 \pm 10 \mathrm{nmol} / \mathrm{mg}$ protein/60 min.

\section{Discussion}

The main end-product from metabolism of L-[1,2${ }^{13}$ C]glutamine was L-glutamate which could enter a number of possible pathways of metabolism in the beta cell including glutathione production, GABA formation, ornithine formation, in addition to 2-oxoglutarate formation [1]. [1,2-13C]5-oxoproline, which is an intermediate of the $\gamma$-glutamyl cycle, was observed in the ${ }^{13} \mathrm{C}$ NMR spectra of cell extracts and incubation medium of BRIN-BD11 beta cells. This observation suggests that glutamine could be entering the cell via $\gamma$-glutamyltransferase as well as through the ASC and 
L transport systems [11]. Higher concentrations of 5oxoproline were detected in the incubation medium but we have determined that the 5-oxoproline associated with the media was derived from spontaneous conversion from extracellular L-glutamine. We observed statistically significant activities of the enzymes $\gamma$-glutamyltransferase and $\gamma$-glutamylcysteine synthetase which form part of the $\gamma$-glutamyl cycle. ${ }^{13} \mathrm{C}$ NMR data in this paper have shown that on addition of $2 \mathrm{mmol} / \mathrm{l}$ glutamine to medium containing the glutathione precursors L-[2-13 C]glycine and L-cysteine, the intensity of the glutathione peak increased. Despite an early report of beta-cell $\gamma$-glutamyltransferase and related $\gamma$-glutamyl cycle activity [23] this route of L-glutamine metabolism has largely been ignored. The activity of beta-cell phosphate-dependent glutaminase was very high and well in excess of the $\gamma$ glutamyltransferase activity suggesting that glutamine can be metabolised by at least two key pathways in the beta cell but that the glutaminase pathway is quantitatively the most important. The L-glutamate formed could enter the $\gamma$-glutamyl cycle (Fig. 1) resulting in increased production of glutathione reported.

Our data have also provided evidence for 2-oxoglutarate (derived from D-glucose) flux through an aminotransferase resulting in the production of L-glutamate. Addition of the aminotransferase inhibitor, aminooxyacetate, attenuated L-glutamate production from D-glucose (with no observable glutamate in the ${ }^{13} \mathrm{C}$ NMR spectra). Thus it seems that under physiological and metabolic conditions in the beta cell, L-glutamate conversion to 2-oxoglutarate was catalysed by GDH [17] but that 2-oxoglutarate conversion to L-glutamate was catalysed by an aminotransferase reaction. Thus L-glutamate is an important intracellular metabolite in the beta cell which can be formed from L-glutamine or D-glucose.

The formation of glutathione, an intracellular thiol, via the $\gamma$-glutamyl cycle from L-glutamate is important for cellular antioxidant defences [37, 38, 39, 40] but could also play a role in enhancing or maintaining mitochondrial function $[41,42]$. Thus glutathione could indirectly, through increasing the ATP to ADP ratio, affect early as well as late signalling events in the nutrient stimulated insulin secretory process. Previous studies on the effects of glutathione on insulin secretion in pancreatic islets have shown that a reduction in glutathione content resulted in a decrease in glucose-stimulated insulin secretion [25]. Glucose was found to increase reduced glutathione (GSH) and decrease oxidised glutathione (GSSG) leading to the hypothesis that glucose modifies the redox state of NADPH/NADP and GSH/GSSG and thus modulates the sensitivity of the beta cell to the release of insulin by glucose [25]. A study of the importance of glutathione reductase showed that a lower GSH content caused an inhibition of L-glutamine and L-leucine-dependent insulin release [43]. In contrast, attenuation of $\gamma$-glutamylcysteine synthetase in the cell line MIN 6 resulted in low cellular glutathione enhanced rates of insulin secretion [44]. The latter study used an assay based on a measurement of released insulin after $24 \mathrm{~h}$ as opposed to the widely accepted method of brief acute incubation (20-60 $\mathrm{min}$ ) followed by insulin measurement. The $24 \mathrm{~h}$ incubation period would not provide data on the critical acute '1 ${ }^{\text {st }}$ phase' insulin release which is absolutely dependent on cell metabolism.

The formation of glutathione, via the $\gamma$-glutamyl cycle, is important for both cellular antioxidant defences and enhanced mitochondrial function. The respiratory chain (electron transport chain) includes four individual enzyme complexes (I-IV). The enzyme complexes, notably NADH-ubiquinone oxidoreductase (complex I) and cytochrome $c$ oxidase (complex IV) can be inhibited by reactive oxygen and nitrogen species such as nitric oxide. Nitric oxide production is stimulated in a wide variety of conditions, including nutrient availability in islet cells, where it was shown that nitric oxide generation resulted in a decreased glucose-induced insulin release [45]. Complex I inhibition by nitric oxide is facilitated, in vitro, by depletion of reduced glutathione [46]. Additionally apoptotic cell death is associated with reduced intracellular GSH concentrations and the production of ROI [42]. The release of cytochrome $c$ from the mitochondrial inner membrane is essential for some forms of stressmediated apoptosis as it activates the Apaf-1/caspase 9 complex, which in turn activates caspase 3 thus precipitating apoptosis [47]. However, even a low level of cytochrome $c$ release will result in impaired mitochondrial ATP production. GSH could actually prevent the release of cytochrome $c$, perhaps through interaction with bcl-2 [48]. We have reported increased beta-cell glutathione concentrations in the presence of L-glutamine (compared to glucose alone). Thus we propose that by maintaining cellular GSH concentration and thus optimising mitochondrial function, Lglutamine may influence nutrient-induced insulin secretion. It is possible that maximal glucose-dependent stimulation of insulin secretion in this condition is dependent on glucose derived glutamate, which by virtue of GSH production, enhances ATP production and thus insulin secretion.

Our data show that although the addition of glucose did not alter the consumption of L-glutamine, it decreased the rate of oxidative L-glutamine metabolism (e.g. the $\left[1-{ }^{13} \mathrm{C}\right]$ aspartate and $\left[4-{ }^{13} \mathrm{C}\right]$ aspartate peaks were reduced in magnitude) resulting in an increase in glutamate concentration. This agrees with results reported by [12] where glucose inhibited glutaminolysis in pancreatic islets while inhibiting GDH. In this proposed mechanism glucose increased GTP concentrations and decreased ADP. The GTP to ADP ratio could influence GDH activity and thus regulate glutaminolysis. It is possible that a decrease in glutami- 
nolysis in the presence of glucose is responsible for the absence of a stimulatory effect of the amino acid. In contrast it is possible that activation or overexpression of GDH in the beta cell allows for greater flux of glutamine/glutamate carbon in the 2-oxoglutarate direction. The result is enhanced insulin secretion. The production of labelled glutamate from $\left[1-{ }^{13} \mathrm{C}\right]$ glucose decreased $(p<0.05)$ in the presence of L-glutamine and the specific enrichment of L-glutamate from labelled D-glucose decreased demonstrating that L-glutamate is produced preferably from L-glutamine via glutaminase in these conditions. L-leucine has been proposed to stimulate L-glutamine metabolism and insulin secretion via allosteric activation of GDH [49]. However, an alternative explanation for the L-leucine-dependent stimulation of insulin secretion is metabolism via branched-chain keto-acid dehydrogenase, conversion to acetyl-CoA and subsequent oxidation [50].

In addition to 2-oxoglutarate formation and glutathione production L-glutamate can enter a number of possible pathways of metabolism in the beta cell including GABA formation and ornithine formation [1]. GABA might not have been detected in our cellular extracts due to a high activity of enzymes of the GABA shunt which will return carbon back to the TCA cycle in the form of succinate. L-glutamate could be converted to pyrroline 5-carboxylate and onward to L-proline, a pathway known to exist in the liver and small intestine. This would explain the ${ }^{13} \mathrm{C}$ peak associated with L-proline detected in our betacell extracts.

In summary L-glutamine metabolism is important for L-glutamate and glutathione production in a clonal beta-cell line. Additionally we provide evidence for D-glucose conversion to L-glutamate via 2-oxoglutarate in a transamination reaction. The new route of $\mathrm{L}$ glutamine metabolism described here seems to be especially important in the beta cell, due to optimisation of mitochondrial function. Thus L-glutamine is used by the beta cell not only for oxidation but also for glutathione production. We speculate that in conditions where activation or overexpression of GDH activity is promoted, the metabolism of L-glutamine will contribute to a rise in the ATP to ADP ratio, thus inactivating the $\mathrm{K}^{+}{ }_{\text {ATP }}$ channel and depolarising the plasma membrane [4]. In conditions where extracellular Lglutamine is limiting, D-glucose metabolism could provide the L-glutamate essential for glutathione production. Our work therefore supports the hypothesis that cytosolic glutamate generation is an important factor for the regulation of insulin secretion [5, 18] but we suggest that downstream metabolites of glutamate metabolism, e.g. glutathione, confer regulatory effects on insulin secretion.

Acknowledgements. This work was generously supported by the Health Research Board (HRB) of Ireland and the Research Development Office of Northern Ireland Department for Health and Personal Social Services. We would like to ac- knowledge also The Wellcome Trust (Grant No. 055637/Z/98) for funding the DRX 500 NMR spectrometer and for supporting C. Hewage. L. Brennan was the recipient of a Conway Institute (University College Dublin) Research Fellowship and more recently a HRB Postdoctoral Fellowship.

\section{References}

1. Newsholme P, Procopio J, Ramos Lima MM, Pithon-Curi TC, Curi R (2003) Glutamine and glutamate-their central role in cell metabolism and function. Cell Biochem Funct 21:1-9

2. Malaisse-Lagae F, Sener A, Garcia-Morales P, Valverde I, Malaisse WJ (1982) The stimulus-secretion coupling of amino acid-induced insulin release. Influence of a nonmetabolized analog of leucine on the metabolism of glutamine in pancreatic islets. J Biol Chem 257:3754-3758

3. Rasschaert J, Flatt PR, McClenaghan NH, Malaisse WJ (1996) Amino acid oxidation in BRIN-BD11 islet cells. Med Sci Res 24:691-692

4. Wollheim CB (2000) Beta-cell mitochondria in the regulation of insulin secretion: a new culprit in Type II diabetes. Diabetologia 43:265-277

5. Maechler P, Wollheim CB (1999) Mitochondrial glutamate acts as a messenger in glucose-induced insulin exocytosis. Nature 402:595-596

6. McClenaghan NH, Barnett CR, O'Harte FPM, Flatt PR (1996) Mechanisms of amino acid-induced insulin secretion from the glucose-responsive BRIN-BD11 pancreatic $\beta$-cell line. J Endocrinol 15:349-357

7. MacDonald MJ, Fahien LA (2000) Glutamate is not a messenger in insulin secretion. J Biol Chem 275:34025-34027

8. Bertrand G, Ishiyama N, Nenquin M, Ravier MA, Henquin J-C (2002) The elevation of glutamate content and the amplification of insulin secretion in glucose-stimulated pancreatic islets are not causally related. J Biol Chem 277: 32883-32891

9. Sener A, Mercan D, Malaisse WJ (2001): Enzymic activities in two populations of purified rat islet beta-cells. Int $\mathbf{J}$ Mol Med 8:285-289

10. Rasschaert J, Flatt PR, Barnett CR, McClenaghan NH, Malaisse WJ (1996) D-glucose metabolism in BRIN-BD11 islet cells. Biochem Mol Med 57:97-105

11. Prentki M, Renold AE (1983) Neutral amino acid transport in isolated rat pancreatic islets. J Biol Chem 258:1423914244

12. Gao Z-Y, Li G, Najafi H, Wolf BA, Matschinski FM (1999): Glucose regulation of glutaminolysis and its role in insulin secretion. Diabetes 48:1535-1542

13. Malaisse WJ, Sener A, Malaisse-Lagae F et al. (1982) The stimulus-secretion coupling of amino acid-induced insulin release: metabolic response of pancreatic islets of L-glutamine and L-leucine. J Biol Chem 257:8731-8737

14. Stanley CA, Lieu YK, Hsu BY et al. (1998) Hyperinulinism and hyperammonemia in infants with regulatory mutations of the glutamate dehydrogenase gene. N Engl J Med 338:1352-1357

15. Stanley CA, Fang J, Kutyna K et al. (2000) Molecular basis and characterization of the hyperinsulinism/hyperammonemia syndrome: predominance of mutations in exons 11 and 12 of the glutamate dehydrogenase gene. Diabetes 49:667-673

16. MacMullen C, Fang J, Hsu BYL et al. (2001) The Hyperinsulinism/Hyperammonemia syndrome in children with regulatory mutations in the inhibitory guanosine triphosphate 
binding domain of glutamate dehydrogenase. J Clin Endocrinol Metab 86:1782-1787

17. Tanizawa Y, Nakai K, Sasaki T et al. (2002) Unregulated elevation of glutamate dehydrogenase activity induces glutamine-stimultaed insulin secretion- identification and characterization of a GLUD1 gene mutation and insulin secretion studies with MIN6 cells overexpressing the mutant glutamate dehydrogenase. Diabetes 51:712-717

18. Rubi B, Ishihara H, Hegardt FG, Wollheim CB, Maechler P (2001) GAD65-mediated glutamate decarboxylation reduces glucose-stimulated insulin secretion in pancreatic beta cells. J Biol Chem 276:36391-36396

19. Hellman B, Sehlin J, Taljedal IB (1971) Uptake of alanine, arginine and leucine by mammalian pancreatic $\beta$-cells. Endocrinology 89:1432-1439

20. Michalik M, Nelson J, Erecinska M (1992) Glutamate production in islets of Langerhans: properties of phosphate-activated glutaminase. Metabolism 41:1319-1326

21. Curthoys NP, Watford M (1995) Regulation of glutaminase activity and glutamine metabolism. Ann Rev Nutr 15:133-159

22. Nissim I, States B, Nissim I, Yudkoff M (1991) The role of $\gamma$-glutamyl transpeptidase in glutamine metabolism by cultured human kidney cells. Contrib Nephrol 92:191-192

23. Anjaneyulu K, Anjaneyulu R, Senner A, Malaisse WJ (1981) $\gamma$-glutamyltranspeptidase activity in pancreatic islets. FEBS Lett 125:57-59

24. Brennan L, Shine A, Hewage C et al. (2002) A NMR based demonstration of substantial oxidative L-alanine metabolism and L-alanine enhanced glucose metabolism in a clonal pancreatic $\beta$-cell line-metabolism of L-alanine is important to the regulation of insulin secretion. Diabetes 51:1714-1721

25. Ammon HPT, Grimm A, Lutz S, Wagner-Teschner D, Händel M, Hagenloh I (1980) Islet glutathione and insulin release. Diabetes 29:830-834

26. McClenaghan NH, Flatt PR (1999) Engineering cultures insulin-secreting pancreatic $\beta$-cell lines. J Mol Med 77:235-243

27. McClenaghan NH, Barnett CR, Ah-Sing E et al. (1996) Characterization of a novel glucose-responsive insulin-secreting cell line, BRIN-DB11, produced by electrofusion. Diabetes 45:1132-1140

28. O'Harte FPM, Mooney MH, Flatt PR (1999) N-terminally glycated gastric inhibitory polypeptide exhibits amino-peptidase resistance and enhanced anti-hyperglycemic activity. Diabetes 48:758-765

29. Chapman JC, McClenaghan NH, Cosgrove $\mathrm{KE}$ et al. (1999) ATP-sensitive potassium channels and efaroxaninduced insulin release in the elctrofusion-derived BRINBD11 beta-cell line. Diabetes 48:2349-2357

30. Saldago, AP, Santos RM, Fernandez AP, Tome AR, Flatt PR, Rosario LM (2000) Glucose-mediated $\mathrm{Ca}^{2+}$ signalling in clonal insulin-secreting BRIN-BD11 cells: evidence for mixed model of cellular activation. Int $\mathrm{J}$ Biochem Cell Biol 32:557-569

31. Lowry OH, Rosenbrough NJ, Farr AL, Randall RJ (1951) Protein measurement with folin phenol reagent. J Biol Chem 193:265-275

32. Finucane MD, Hudson EA, Malthouse JPG (1989) $\mathrm{A}^{13} \mathrm{C}$ NMR investigation of the ionizations within an inhibitoralpha-chymotrypsin complex. Evidence that both alphachymotrypsin and trypsin stabilize a hemiketal oxyanion by similar mechanisms. Biochem J 258:853-859

33. Fan TWM (1996) Metabolite profiling by one- and two- dimensional NMR analysis of complex mixtures. Prog NMR Spectrosc 28:161-219
34. Chateil JF, Biran M, Thiaudière E, Canioni P, Merle M (2001) Metabolism of $\left[1{ }^{13} \mathrm{C}\right]$ glucose and $\left[2-{ }^{13} \mathrm{C}\right]$ acetate in the hypoxic rat brain. Neurochem Int 38:399-407

35. Windmueller HG, Spaeth AE (1974): Uptake and metabolism of plasma glutamine by the small intestine. J Biol Chem 249:5070-5079

36. Richman PG, Orlowski M, Meister A (1973) Inhibition of $\gamma$-glutamylcysteine synthetase by L-methionine-S-sulfoximine. J Biol Chem 248:6684-6690

37. Watson RWG, Rotstein OD, Nathens AB, Dackiw APB, Marshall JC (1996) Thiol-mediated redox regulation of neutrophil apoptosis. Surgery 120:150-158

38. Macho A, Hirsch T, Marzo I et al. (1997) Glutathione depletion is an early and calcium elevation is a late event of thymocyte apoptosis. J Immunol 158:4612-4619

39. Tiedge M, Lortz S, Munday R, Lenzen S (1999) Protection against the cooperative toxicity of nitric oxide and oxygen free radicals by overexpression of antioxidant enzymes in bioengineered insulin-producing RINm5F cells. Diabetologia 42:849-855

40. Tiedge M, Lortz S, Munday R, Lenzen S (1998) Complementary action of antioxidant enzymes in the protection of bioengineered insulin-producing RINm5F cells against the toxicity of reactive oxygen species. Diabetes 47:15781585

41. Bolanos JP, Heales SJ, Peuchen S, Barker JE, Land JM, Clark JB (1996) Nitric oxide-mediated mitochondrial damage: a potential neuroprotective role for glutathione. Free Radic Biol Med 21:995-1001

42. O'Neill A, O'Neill S, Hegarty NJ et al. (2000) Glutathione depletion-induced neutrophil apoptosis is caspase-3 dependent. Shock 14:605-609

43. Malaisse WJ, Dufrane SP, Mathias PCF et al. (1985) The coupling of metabolic to secretory events in pancreatic islets. The possible role of glutathione reductase. Biochim Biophys Acta: 844:256-264

44. Kondo H, Mori S, Takino H et al. (2000) Attenuation of expression of $\gamma$-glutamylcycteine synthetase by ribozyme transfection enhance insulin secretion by pancreatic $\beta$ cell line, MIN6. Biochem Biophys Res Comm 278:236-240

45. Salehi A, Parandeh F, Lundquist I (1998) Signal transduction in islet hormone release: interaction of nitric oxide with basal and nutrient-induced hormone responses. Cell Signal 10:645-651

46. Clementi E, Brown GC, Feelisch M, Moncada S (1998) Persistent inhibition of cell respiration by nitric oxide: crucial role of S-nitrosylation of mitochondrial complex I and protective action of glutathione. Proc Natl Acad Sci USA 95:7631-7636

47. DiPietrantonin AM, Hsieh T, Wu JM (1999) Activation of caspase 3 in HL-60 cells exposed to hydrogen peroxide. Biochem Biophys Res Commun 255:477-482

48. Voehringer DW, McConkey DJ, McDonnell TJ, Brisbay S, Meyn RE (1998) Bcl-2 expression causes redistribution of glutathione to the nucleus. Proc Natl Acad Sci USA 95: 2956-2960

49. Sener A, Malaisse WJ (1980) L-leucine and a nonmetabolized analogue activate pancreatic islet glutamate dehydrogenase. Nature 288:187-189

50. MacDonald MJ, McKenzie DI, Kaysen JH et al. (1991) Glucose regulates leucine-induced insulin release and the expression of the branched-chain ketoacid dehydrogenase E1a subunit gene in pancreatic islets. J Biol Chem 266: 1335-1340 